\title{
Ендоваскулярне закриття відкритого овального вікна для профілактики криптогенного інсульту у пацієнтів молодого віку
}

\author{
Дітківський І. О., Мазур О. А., Ящук Н. С., Черпак Б. В., Єрмолович Ю. В. \\ ДУ «Національний інститут серцево-судинної хірургії імені М. М. Амосова НАМН» (Київ)
}

\begin{abstract}
Однією з причин криптогенних інсультів в осіб молодого та середнього віку є відкрите овальне вікно, що уможливлює парадоксальну емболію судин мозку тромбами з венозної системи великого кола кровообігу. За даними літератури останніх років, закриття овального вікна оклюдером є оптимальним способом профілактики повторних криптогенних інсультів.

У ДУ «НІССХ імені М. М. Амосова» 2011 по 2018 р. було виконано 10 процедур ендоваскулярного закриття відкритого овального вікна оклюдером у молодих пацієнтів, які мали в анамнезі криптогенні інсульти та парадоксальну системну емболізацію. Успішність процедури склала $100 \%$, серйозні ускладнення в післяопераційному та віддаленому періоді відсутні. Всі пацієнти живі та відмічають суб'єктивне покращення стану (зникли головний біль та мігрені). В одному випадку через 1,5 року після операції відбувся підтверджений на МРТ ішемічний інсульт без залишкових змін, імовірною причиною якого була емболія мікротромбами з вушка лівого передсердя (в анамнезі наявна аритмія невизначеного генезу), оскільки допплерЕхоКГ та бульбашковий тест визначили відсутність шунта між правими та лівими відділами серця.

Таким чином, наші дані підтверджують ефективність і безпечність ендоваскулярного закриття відкритого овального вікна для профілактики криптогенних тромбоемболій.
\end{abstract}

Ключові слова: відкрите овальне вікно, парадоксальна емболія, криптогенний інсульт, ендоваскулярне закриття оклюдером.

Гострі порушення мозкового кровообігу (ГПМК) посідають друге місце серед причин смерті у світі [1]. Саме тому важливим є визначення способу профілактики інсультів, для чого необхідне ретельне вивчення їх етіології.

Гостре порушення мозкового кровообігу, причину якого, попри ретельне обстеження, точно з'ясувати не вдалося, називається криптогенним інсультом. Залежно від доступного рівня діагностики частка таких інсультів становить від 10 до 40\%, в середньому сягаючи $30 \%[2]$

Однією з можливих причин криптогенних інсультів вважають відкрите овальне вікно (ВОВ). Це - сполучення між правим і лівим передсердям, що у більшості людей закривається в перші три місяці життя, але приблизно у $25 \%$ людей залишається і в дорослому віці. Відкрите овальне вікно не вважається вадою серця i розглядається як індивідуальна особливість, воно пропускає кров переважно зліва направо завдяки різниці тисків між передсердями. Проте за певних умов тиск у правому передсерді підвишується, в результаті чого напрямок скиду крові може змінитися, і венозні тромби великого кола кровообігу можуть потрапляти у ліві відділи серця та спричинити емболію артерій великого кола кровообігу. Середній діаметр ВОВ становить 4,9 мм, тобто воно може пропускати емболи, достатньо великі, щоб викликати оклюзію стовбура середньої мозкової артерії (3 мм) та головних кортикальних гілок (1 мм) [2].

На користь того, що ВОВ може бути причиною криптогенних інсультів, свідчить той факт, що серед осіб до 55 років, які перенесли криптогенний інсульт, поширеність ВОВ вища, ніж серед загальної популяції: вона сягає 40-50\% [3]. Для підтвердження наявності шунта між правими та лівими відділами серця використовують ЕхоКГ та ультразвукову допплерографію судин голови.

До недавнього часу практичні рекомендації не вказували доцільним рутинне ендоваскулярне закриття ВОВ для профілактики повторних інсультів, надаючи перевагу медикаментозній терапії (антикоагулянти та/або антиагреганти) [4, 5]. Три великі рандомізовані контрольовані дослідження останніх років CLOSURE I [6], PC [7] і RESPECT [8] - не показали істотної різниці між ендоваскулярним закриттям ВОВ та медикаментозною терапією для профілактики повторного інсульту, хоча два з них вказували на потенційну перевагу ендоваскулярного закриття без достатньої статистичної достовірності [7, 8]. Але вже наступні дослідження - REDUCE [9] і CLOSE [10] - свідчать про істотну перевагу транскатетерного закриття ВОВ у зниженні частоти повторних інсультів в осіб, що перенесли криптогенний інсульт. Ці п'ять великих рандомізованих контрольованих досліджень проводилися в 
США і країнах Європи. Останнє дослідження з Південної Кореї - DEFENSE-PFO [11] - також свідчить на користь ендоваскулярного закриття ВОВ у пацієнтів високого ризику.

За останній рік були опубліковані численні метааналізи, що порівнювали закриття ВОВ з медикаментозною терапією при криптогенному інсульті [12-16]. Вони беруть до уваги дані зазначених вище рандомізованих контрольованих досліджень і доходять висновку, що в пацієнтів із криптогенним інсультом закриття ВОВ має перевагу перед медикаментозною терапією для профілактики повторних ГПМК, особливо в пацієнтів із помірним або вираженим право-лівим шунтом. Автори мета-аналізів відзначають доцільність оновлення практичних рекомендацій відповідних товариств з урахуванням актуальних досліджень. Також в окремому дослідженні було виявлено, що закриття ВОВ виявляється економічно вигіднішим за стратегію медикаментозного лікування [17].

В цій роботі ми представляємо наш досвід ендоваскулярного закриття ВОВ у молодих пацієнтів з метою профілактики криптогенних інсультів.

Матеріали та методи. В ДУ НІССХ імені М. М. Амосова з 2011 до 2018 р. було прооперовано 10 пацієнтів молодого віку з метою профілактики парадоксальної емболії судин головного мозку та інших судин артеріального русла (табл. 1). Усі пацієнти мали сполучення на рівні передсердь - 8 ВОВ та 2 ДМПП. Вік пацієнтів коливався від 16 до 53 років, 8 з них було жіночої статі, 2 - чоловічої. В анамнезі 7 пацієнтів мали ГПМК ішемічного типу, підтверджені на МРТ (одна жінка перенесла інсульт двічі), 2 - транзиторні ішемічні атаки (TIA), в 1 випадку була емболія артерій стопи. Суб'єктивно більшість пацієнтів (8) мали скарги на сильний головний біль і мігрені. Варто зазначити, що сама по собі комбінація мігренеподібних болів із ВОВ не була показанням до втручання при відсутності парадоксальної системної емболії в анамнезі, але бралася до уваги як окремий пре диктор - разом із палінням, тромбозом глибоких вен, ТЕЛА в анамнезі та іншими факторами, зазначеними в літературі [3].

Критерієм включення була наявність в анамнезі ГПМК, ТІА або системної парадоксальної емболізації у пацієнтів зі сполученням на рівні передсердь і підтвердженим шунтом із правого передсердя в ліве, всі причини ішемічних подій, крім парадоксальної емболії у яких були виключені. Підтвердження скиду крові справа наліво показував позитивний результат бульбашкового тесту - пацієнтам у периферичну вену вводили вспінений колоїдний розчин і після проби

\section{Таблиця 1}

\begin{tabular}{|c|c|c|c|c|c|c|c|}
\hline П-т & Рік & $\begin{array}{c}\text { Вік на } \\
\text { момент } \\
\text { операції }\end{array}$ & Стать & Анамнез & Пристрій & Контроль & Результат \\
\hline $\mathrm{KO}$ & 2011 & 37 & ж & $\begin{array}{l}\text { ГПМК у } \\
2011 \text { р. ішемічного типу }\end{array}$ & $\begin{array}{l}\text { Amplatzer PFO } \\
\text { occluder } 25 \mathrm{~mm}\end{array}$ & $\begin{array}{l}\text { Через } 4 \text { міс., } \\
\text { далі зв’язок } \\
\text { втрачено }\end{array}$ & $\begin{array}{l}\text { Мігрені зникли, повторних } \\
\text { інсультів не задокументовано }\end{array}$ \\
\hline ГО & 2013 & 43 & ж & $\begin{array}{l}\text { Мігрені, ТІА, тромбоз } \\
\text { глибоких вен нижніх } \\
\text { кінцівок }\end{array}$ & $\begin{array}{l}\text { MemoPart PFO } \\
\text { occluder } 34 \text { mm }\end{array}$ & $\begin{array}{l}\text { На момент на- } \\
\text { писання статті }\end{array}$ & $\begin{array}{l}\text { Ішемічний мікроінсульт у } \\
2014 \text { р., мігрені зникли }\end{array}$ \\
\hline $\mathrm{KT}$ & 2014 & 30 & ж & $\begin{array}{l}\text { Два ГПМК у } 2014 \text { р. } \\
\text { ішемічного типу }\end{array}$ & $\begin{array}{l}\text { Amplatzer cribriform } \\
\text { occluder } 25 \mathrm{~mm}\end{array}$ & $\begin{array}{l}\text { На момент на- } \\
\text { писання статті }\end{array}$ & $\begin{array}{l}\text { Повторних інсультів не задо- } \\
\text { кументовано, мігрені зникли }\end{array}$ \\
\hline 40 & 2016 & 53 & ж & TIA, мігрені & $\begin{array}{l}\text { Nit-Occlud PFO } \\
\text { occluder } 26 \mathrm{~mm}\end{array}$ & $\begin{array}{l}\text { На момент на- } \\
\text { писання статті }\end{array}$ & $\begin{array}{l}\text { Мігрені зникли, повторних ТІА } \\
\text { не задокументовано }\end{array}$ \\
\hline CA & 2016 & 21 & & $\begin{array}{l}\text { ГПМК в } 2017 \text { р. } \\
\text { ішемічного типу }\end{array}$ & $\begin{array}{l}\text { MemoPart PFO } \\
\text { occluder } 24 \mathrm{~mm}\end{array}$ & $\begin{array}{l}\text { На момент на- } \\
\text { писання статті }\end{array}$ & $\begin{array}{l}\text { Повторних інсультів не задо- } \\
\text { кументовано }\end{array}$ \\
\hline MM & 2017 & 29 & ж & $\begin{array}{l}\text { Додатковий ДМПП } 6 \text { мм і } \\
\text { парадоксальна емболія в } \\
\text { судини стопи, } 2017 \text { р. }\end{array}$ & $\begin{array}{l}\text { MemoPart ASD } \\
\text { occluder } 15 \mathrm{~mm}\end{array}$ & $\begin{array}{l}\text { На момент на- } \\
\text { писання статті }\end{array}$ & $\begin{array}{l}\text { Повторних емболій не задо- } \\
\text { кументовано }\end{array}$ \\
\hline $\mathrm{CB}$ & 2017 & 29 & M & $\begin{array}{l}\text { ГПМК у } 2015 \text { р. } \\
\text { ішемічного типу }\end{array}$ & $\begin{array}{l}\text { MemoPart PFO } \\
\text { occluder } 34 \mathrm{~mm}\end{array}$ & $\begin{array}{l}\text { На момент на- } \\
\text { писання статті }\end{array}$ & $\begin{array}{l}\text { Повторних інсультів не задо- } \\
\text { кументовано, мігрені зникли }\end{array}$ \\
\hline $3 \mathrm{~K}$ & 2017 & 28 & ж & $\begin{array}{l}\text { Множинні точкові } \\
\text { ДМПП, ГПМК у } 2016 \text { р. } \\
\text { ішемічного типу, } \\
\text { численні ТІА }\end{array}$ & $\begin{array}{l}\text { MemoPart PFO } \\
\text { occluder } 34 \mathrm{~mm} \\
\text { + MemoPart PFO } \\
\text { occluder } 24 \mathrm{~mm}\end{array}$ & $\begin{array}{l}\text { На момент на- } \\
\text { писання статті }\end{array}$ & $\begin{array}{l}\text { Повторних інсультів не задо- } \\
\text { кументовано, мігрені зникли }\end{array}$ \\
\hline МБ & 2017 & 16 & M & $\begin{array}{l}\text { ГПМК у } 2017 \text { р. } \\
\text { ішемічного типу }\end{array}$ & $\begin{array}{l}\text { MemoPart PFO } \\
\text { occluder } 28 \mathrm{~mm}\end{array}$ & $\begin{array}{l}\text { На момент на- } \\
\text { писання статті }\end{array}$ & $\begin{array}{l}\text { Повторних інсультів не задо- } \\
\text { кументовано }\end{array}$ \\
\hline MI & 2018 & 46 & ж & $\begin{array}{l}\text { ГПМК у } 2017 \text { р. } \\
\text { ішемічного типу }\end{array}$ & $\begin{array}{l}\text { MemoPart PFO } \\
\text { occluder } 24 \mathrm{~mm}\end{array}$ & $\begin{array}{l}\text { На момент на- } \\
\text { писання статті }\end{array}$ & $\begin{array}{l}\text { Повторних інсультів не задо- } \\
\text { кументовано, мігрені зникли }\end{array}$ \\
\hline
\end{tabular}


Вальсальви спостерігали наявність бульбашок у лівому передсерді (черезстравохідна ЕхоКГ) або в середній мозковій артерії (транскраніальна ЕхоКГ).

Процедура закриття проводилась у рентген-операційній під контролем черезстравохідної (8 випадків) або інтракардіальної (2 випадки) ЕхоКГ під комбінованою анестезією (седація і місцеве знеболення), доступом через v.femoralis. Протокол закриття не відрізняється від протоколу закриття ДМПП [18], крім використання оклюдерів іншого типу. Середня тривалість процедури становила від 32 до 98 хв., у серед-

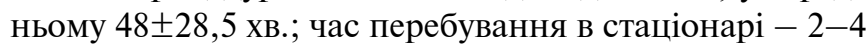
дні. Були використані такі оклюдери: Amplatzer PFO occluder - 2 шт., MemoPart PFO occluder - 7 (в одному випадку множинні дефекти були закриті двома пристроями), MemoPart ASD occluder - 1 шт. (для одночасного закриття ДМПП і BOB), Nit-Occlud PFO occluder - 1 шт. Одразу після імплантації ми проводили бульбашковий тест, у всіх випадках він був негативним. Всі пацієнти після процедури були переведені в палату і через 1-2 дні виписані зі стаціонару. Хворим було призначено варфарин (контроль МНО на рівні 2-2,5) на 3 місяці і ацетилсаліцилову кислоту 3 мг/кг на 6 місяців, ЕхоКГ-контроль на виписку, через 1, 3, 6 , 12 і 24 місяці.

Результати та обговорення. На момент написання статті нам вдалося відстежити 9 із 10 пацієнтів (телефонне опитування), одна пацієнтка зникла з поля зору через 4 місяці після імплантації. Час спостереження - від 7 років до одного місяця. Успішність процедури становить $100 \%$, усі пацієнти живі і не мали серйозних ускладнень у ранньому післяопераційному періоді. Під час трансторакальної ЕхоКГ відмічали адекватне положення оклюдера, відсутність скиду крові на рівні передсердь за даними кольорової допплерівської ЕхоКГ, а також негативний бульбашковий тест. У віддаленому періоді через 1,5 року після операції одна пацієнтка мала ішемічний інсульт (підтверджений на МРТ) без значного неврологічного дефіциту. Інші пацієнти не мали ні інсультів, ні ТІА. Суб'єктивно всі хворі відмічали значне покращення самопочуття (в тому числі пацієнтка з інсультом) завдяки повному зникненню головного болю та мігрені.

До сьогодні існують різні дані щодо доцільності закриття ВОВ у пацієнтів молодої групи для профілактики криптогенного інсульту. При відборі пацієнтів ми керувались загальноприйнятими рекомендаціями і враховували особливість анамнезу пацієнтів. Про вірність нашої тактики свідчить покращення самопочуття пацієнтів, яких ми відібрали на дану процедуру. Одна з наших пацієнток мала підтверджений ішемічний інсульт через 1,5 роки після закриття ВОВ. Причина його невідома, однак ми повністю виключаємо вірогідність спонтанної емболії з венозної системи через овальне вікно, оскільки при допплерівській ЕхоКГ було визна- чено відсутність скиду на рівні перегородки, а також негативний результат бульбашкового тесту. Найбільш імовірною причиною ГПМК у даної пацієнтки ми вважаємо емболію мікротромбами з вушка лівого передсердя (в анамнезі наявна аритмія неясного генезу) або емболію тромбами з лівопередсердного диску оклюдера. Остання причина малоймовірна, оскільки інсульт стався через 1,5 роки після імплантації (на тваринних моделях повна епітелізація спостерігалась від кількох тижнів до трьох місяців після імплантації [19, 20]). Проте існують дані про пізню ендотелізацію імплантованих пристроїв [21, 22], відтак цю причину ми виключати не можемо. На нашу думку, даній пацієнтці був показаний більш тривалий термін прийому антикоагулянтів.

Враховуючи дані літератури та наші результати, ми можемо констатувати ефективність і безпечність даної методики. Відсутність безпосередніх і серйозних віддалених ускладнень та позитивний клінічний ефект дозволяють нам застосовувати ендоваскулярний метод закриття овального вікна для профілактики криптогенних тромбоемболій.

\section{Висновки}

1. Процедура ендоваскулярного закриття ВОВ є безпечною, виправданою та ефективною в когорті пацієнтів, що перенесли криптогенне ГПМК або ТІА.

2. Метод є ефективним способом виключення механізму парадоксальної системної емболізації в досліджуваної групи пацієнтів.

3. Віддалене спостереження пацієнтів обов'язкове, деяким пацієнтам показаний більш тривалий термін прийому антикоагулянтів.

1. Література

2. The top 10 causes of death [Електронний ресурс] // World Health Organization. - 2017. - Режим доступу до ресурcy: http://www.who.int/mediacentre/factsheets/fs310/en/

3. Saver J. Cryptogenic Stroke / J. Saver // N Engl J Med. 2016. - Vol. 374, N 21. - P. 2065-2074.

4. The Risk of Paradoxical Embolism (RoPE) Study: developing risk models for application to ongoing randomized trials of percutaneous patent foramen ovale closure for cryptogenic stroke [Електронний pecypc] / Kent D. M., Thaler D. E. // Trials. - 2011. Vol. 12. - Режим доступу до журналу : https://dx.doi. org/10.1186/1745-6215-12-185

5. Practice advisory: recurrent stroke with patent foramen ovale (update of practice parameter): report of the Guideline Development, Dissemination, and Implementation Subcommittee of the American Academy of Neurology / Messŭ S. R., Gronseth G., Kent D. M. [et al.] // Neurology. - 2016. - Vol. 87. - P. 815-821.

6. American Heart Association Stroke Council, Council on Cardiovascular and Stroke Nursing, Council on Clinical Cardiology, and Council on Peripheral Vascular Disease. Guidelines for the prevention of stroke in patients with stroke and transient ischemic attack: a guideline for healthcare professionals from the American Heart Association/American Stroke Association / Kernan W. N., 
Ovbiagele B., Black H. R. [et al.] // Stroke. - 2014. Vol. 45. - P. 2160-2236.

7. Closure or medical therapy for cryptogenic stroke with patent foramen ovale / Furlan A. J., Reisman M., Massaro J. [et al.] // N Engl J Med. - 2012. - Vol. 366, N 11. - P. 991-999.

8. Percutaneous closure of patent foramen ovale in cryptogenic embolism / Meier B., Kalesan B., Mattle H. P. [et al.] // N Engl J Med. - 2013. - Vol. 368, N 12. - P. 1083-1091.

9. Long-term outcomes of patent foramen ovale closure or medical therapy after stroke / Saver J., Carroll J., Thaler D. [et al.] // N Engl J Med. - 2017. - Vol. 377, N 11. P. $1022-1032$.

10. Patent foramen ovale closure or antiplatelet therapy for cryptogenic stroke / Swndergaard L., Kasner S., Rhodes J. [et al.] // N Engl J Med. - 2017. - Vol. 377, N 11. P. 1033-1042.

11. Patent Foramen Ovale Closure or Anticoagulation vs. Antiplatelets after Stroke / Mas J. L., Derumeaux G., Guillon B. [et al.] // N Engl J Med. - 2017. - Vol. 377, N 11. - P. 1011-1021.

12. Cryptogenic Stroke and High-Risk Patent Foramen Ovale: The DEFENSE-PFO Trial [Електронний ресурс]/ Lee P. H., Song J.-K., Kim J. S. [et al.] // JACC. - 2018. Режим доступу до журналу : https://doi.org/10.1016/j. jacc.2018.02.046

13. Patent foramen ovale closure vs. medical therapy for cryptogenic stroke: a meta-analysis of randomized controlled trials [Електронний pecypc]/ Ahmad Y., Howard J. P., Arnold A. [et al.] // Eur Heart J. - 2018. Режим доступу до журналу : https://doi.org/10.1093/ eurheartj/ehy121

14. Patent foramen ovale closure versus medical therapy after cryptogenic stroke: An updated meta-analysis of all randomized clinical trials [Електронний ресурс] / Kheiri B., Abdalla A., Osman M. [et al.] // Cardiol J. 2018. - Режим доступу до журналу : http://dx.doi. org/10.5603/CJ.a2018.0016

15. Meta-Analysis Comparing Patent Foramen Ovale Closure Versus Medical Therapy to Prevent Recurrent Cryptogenic
Stroke / Ando T., Holmes A. A., Pahuja M. [et al.] // Am J Cardiol. - 2018. - Vol. 121, N 5. - P. 649-655.

16. Percutaneous closure of patent foramen ovale vs. medical treatment for patients with history of cryptogenic stroke: A systematic review and meta-analysis of randomized controlled trials [Електронний ресурс] / Palaiodimos L., Kokkinidis D. G., Faillace R. T. [et al.] // Cardiovasc Revasc Med. - 2018. - Режим доступу до журналу : https://doi.org/10.1016/j.carrev.2018.02.014

17. Transcatheter Closure of Patent Foramen Ovale versus Medical Therapy after Cryptogenic Stroke: A MetaAnalysis of Randomized Controlled Trials / Darmoch F., Al-Khadra Y., Soud M. [et al.] // Cerebrovasc Dis. 2018. - Vol. 45. - P. 162-169.

18. Cost-effectiveness of percutaneous patent foramen ovale closure as secondary stroke prevention [Електронний pecypc] / Tirschwell D. L., Turner M., Thaler D. [et al.] // J Med Econ. - 2018. - P. 1-20. - Режим доступу до журналу : https://doi.org/10.1080/13696998.2018.1456445

19. Carroll J. D. Structural Heart Disease Interventions / J. D. Carroll, J. G. Webb. - Philadelphia : Lippincott Williams \& Wilkins, 2012. - 399 p. - P. 183-189.

20. Transcatheter closure of atrial septal defects. Experimental studies / Lock J. E., Rome J. J., Davis R. [et al.] // Circulation. - 1989. - Vol. 79, N 5. - P. 1091-1099.

21. Transvenous closure of secundum atrial septal defects: preliminary results with a new self-expanding nitinol prosthesis in a swine model / Sharafuddin M. J., Gu X., Titus J. L. [et al.] // Circulation. - 1997. - Vol. 95, N 8. P. 2162-2168.

22. Incidence and Clinical Course of Thrombus Formation on Atrial Septal Defect and Patient Foramen Ovale Closure Devices in 1,000 Consecutive Patients / Krumsdorf U., Ostermayer S., Billinger K. [et al.] // JACC. - 2004. Vol. 43, N 2. - P. 302-309.

23. Endocarditis and Incomplete Endothelialization 12 Years after Amplatzer Septal Occluder Deployment / Nguyen A. K., Palafox B. A., Starr J. P. [et al.] // Tex Heart Inst J. - 2016. - Vol. 43, N 3. - P. 227-231.

\title{
Endovascular closure of patent foramen ovale for cryptogenic stroke prevention in patients of young age
}

\author{
Ditkivskyy I. O., Mazur O. A., Yashchuk N. S., Cherpak B. V., Yermolovych Ju. V.
}

National M. M. Amosov Institute of Cardiovascular Surgery National Academy of Medical Sciences of Ukraine (Kyiv)

One of the causes of cryptogenic stroke in young and middle-aged patients is patent foramen ovale (PFO), which enables paradoxical embolism of cerebral arteries by thrombi from systemic veins. According to latest research, endovascular PFO closure is the optimal method for the prevention of further cryptogenic stroke.

From 2011 to 2018 y 10 procedures of endovascular PFO closure with an occluder in young patients with cryptogenic stroke and paradoxical systemic embolism were performed in National M. M. Amosov Institute of Cardiovascular Surgery. The success rate was $100 \%$, and there were no serious complications in the postoperative and long-term periods. All patients are alive and are reporting subjective improvement (headaches and migraines were gone). In one case 1.5 years after the procedure there was reported an MRI-confirmed ischemic stroke, without residual effects. Its most probable reason was embolism with microthrombi from left atrial appendage (there was reported arrhythmia of undetermined etiology in this patient), because both Doppler echocardiography and bubble-test showed no shunt between right and left heart. 
Our data confirms the effectiveness and safety of endovascular PFO closure for the prevention of cryptogenic thromboembolism.

Key words: patent foramen ovale, paradoxical embolism, cryptogenic stroke, endovascular closure.

\title{
Эндоваскулярное закрытие открытого овального окна для профилактики криптогенного инсульта у пациентов молодого возраста
}

\author{
Дитковский И. А., Мазур А. А., Ящук Н. С., Черпак Б. В., Ермолович Ю. В. \\ ГУ «Национальный институт сердечно-сосудистой хирургии имени Н. М. Амосова НАМН» (Киев)
}

Одной из причин криптогенных инсультов у лиц молодого и среднего возрастов является открытое овальное окно, которое делает возможной парадоксальную эмболию сосудов головного мозга тромбами из венозной системы большого круга кровообращения. Согласно данным литературы последних лет, закрытие овального окна окклюдером - оптимальный способ профилактики повторных криптогенных инсультов.

В ГУ «НИССХ имени Н. М. Амосова» с 2011 по 2018 год было выполнено 10 процедур эндоваскулярного закрытия открытого овального окна окклюдером у молодых пациентов, которые перенесли криптогенные инсульты и парадоксальную системную эмболизацию. Успешность процедуры составила $100 \%$, серьезные осложнения в послеоперационном и отдаленном периоде отсутствовали. Все пациенты живы и отмечают субъективное улучшение состояния (исчезли головная боль и мигрени). В одном случае через 1,5 года после операции произошел подтвержденный на МРТ ишемический инсульт без остаточных изменений, вероятной причиной которого была эмболия микротромбами из ушка левого предсердия (в анамнезе присутствовала аритмия неопределенного генеза), поскольку допплер-ЭхоКГ и пузырьковый тест определили отсутствие шунта между правыми и левыми отделами сердца.

Таким образом, наши данные подтверждают эффективность и безопасность эндоваскулярного закрытия открытого овального окна для профилактики криптогенных тромбоэмболий.

Ключевые слова: открытое овальное окно, парадоксальная эмболия, криптогенный инсульт, эндоваскулярное закрытие окклюдером. 